\title{
EFFECTS OF APPLIED HERBICIDES ON CROP PRODUCTIVITY AND ON WEED INFESTATION IN DIFFERENT GROWTH STAGES OF SUNFLOWER (Helianthus annuus L.)
}

\author{
Simić, M. ${ }^{* 1}$, Dragičević, V. ${ }^{1}$, Knežević, S. ${ }^{2}$, Radosavljević, M. ${ }^{1}$, \\ Dolijanović, Ž. ${ }^{3}$ and Filipović, M. ${ }^{1}$
}

${ }^{1}$ Maize Research Institute, Zemun Polje, S. Bajića 1,

11185 Zemun-Belgrade, Serbia

${ }^{2}$ Haskell Agricultural Laboratory, University of Nebraska, 57905866 Road Concord, Lincoln, NE, USA

${ }^{3}$ Faculty of Agriculture, University of Belgrade, Nemanjina 6 ,

11185 Zemun-Belgrade, Serbia

Received: May 26, 2011

Accepted: June 30, 2011

\section{SUMMARY}

The level of weed infestation directly affects the intensity of competitive relationship between sunflower crops and weeds. The greatest damage is caused by annual, broad-leaf and invasive weeds, such as Ambrosia artemisiifolia L., Xanthium strumarium L. and Datura stramonium L. Suppression of these weeds is difficult because of deficiency of adequate herbicides and because in years with dry springs, such as in 2009, the use of herbicides gives no results. This two-year study dealt with the observed effects of pre-emergence flurochloridone $+\mathrm{s}$-metolachlor herbicides on the distribution of weeds in different stages of sunflower development. Weed infestation was estimated over the sunflower developmental stages, i.e., in the periods when weeds were removed and when the total fresh and dry biomass of the weed species was determined. Simultaneously, in order to monitor the effects of weeds in dependence on herbicides application and the duration of competition, the sunflower plant height was measured. At the end of the life cycle, the yield and the oil content of the sunflower seeds were established.

The total fresh weed biomass changed in dependence on the sunflower developmental stages and was always lower on the herbicide-treated area. This affected the sunflower plant height, yield and the oil content, which were higher, on the average, in the variants with herbicide applications $(70.4 \mathrm{~cm}$, $2959.7 \mathrm{~kg} \mathrm{ha}^{-1}$ and $42.0 \%$ ) than in the variants without herbicides application (57.4 $\mathrm{cm}, 2711.1 \mathrm{~kg} \mathrm{ha}^{-1}$ and $40.1 \%$ ). Weed suppression in the sunflower crop has to be done with adequate herbicides and in due time in order to suppress a significant reduction in morphological and yield parameters.

* Corresponding author: Phone: ++381 113756 704; Fax: ++381 113756 707; e-mail: smilena@mrizp.rs 


\section{Key words: flurochloridone, s-metolachlor, sunflower growth stages, weeds, yield}

\section{INTRODUCTION}

The level of weed infestation of sunflower (Helianthus annuus L.) differs over locations and directly affects the intensity of the competitive relationships between crops and weeds, which results in lower or greater yield losses (Vratarić, 2004). Sunflower meets $14 \%$ of the world oil production demands (FAO 2002) and most of the consumer demands in Serbia. Furthermore, sunflower oil has found widespread acceptance as high quality, edible oil throughout much of the world (Demirer et al., 2004).

The high competitive ability of sunflower was verified by studies in competition with common lambsquarters, wild mustard and greater ammi (Onofrio and Tei, 1994). Since the time of emergence of both weeds and crops, which period is very important in their competitive relationships, it is notied that sunflower is not always such a good competitor because of its slow growth in the initial stage. Regardless of the fact that sunflower has large leaves and a good canopy formation, weeds always have the advantage at the outset due to sunflower's slow initial growth. It is especially important to pay attention to the dominant weed species, considering that different species within one community differently affect the growth and yield of sunflower. Sunflower is a thermophile plant and is usually sown in mid-spring, when a large number of weeds, especially troublesome ones, ( $A$. artemisiifolia, X. strumarium, D. stramonium, A. retroflexus, etc.) have already emerged. Weeds compete with crop plants for nutrients, soil moisture, light and space. The yield reduction due to weeds in sunflower crops was estimated to be as high as $81 \%$ (Jaykumar et al., 1988). Therefore, timely weed control is essential for optimising sunflower yields. Having information on the time of weed emergence in relation to crop emergence is an important factor in making decisions on weed control (Bosnić and Swanton, 1997). A study of the influence of redroot pigweed (A. retroflexus L.) on the dry matter of maize and soybean showed that each new leaf of the cultivated plants developed with the loss of $2 \%$ if weeds had not been removed at the proper time (Knežević et al., 1997).

Chemical weed control appears to hold great promise in accomplishing effective, timely and economic weed suppression (Castro-Tendero and García-Torres, 1995). Although the relative importance of soil-applied herbicides in sunflower production has declined with the introduction of effective post-emergence herbicides and the development of herbicide-resistant cultivars, these products are still in use because of their reliable price and effective weed control. A sufficiently selective herbicide applied at the appropriate time is essential for successful weed control. Chemical weed control in sunflower crops is difficult, due to the lack of efficient post-emergence broad-leaf herbicides and because soil herbicides are not suffi- 
ciently efficient in the suppression of small-seeded weed species (Malidža et al., 2004; 2005). In recent time, products based on flurochloridone, acetochlor, terbutylazine, oxadiazon, oxyfluorfen and other active ingredients have been applied in soil treatments for the suppression of annual broad-leaf and some grass weeds in sunflower (Channappagoudar et al., 2008; Konstantinović et al., 2010).

Present study observed, over a two-year period, the effects of the application of herbicides (flurochloridone + s-metolachlor) on weeds and the plant height as a result of weed-crop competition at different developmental stages of sunflower. The grain yield and the oil content of sunflower seeds were also measured in order to confirm the importance of successful weed control.

\section{MATERIAL AND METHODS}

The trial was carried out on the experimental field of the Maize Research Institute, Zemun Polje, in the vicinity of Belgrade (44 52' N, 20 20' E) during 2008 and 2009. The soil is slightly calcareous chernozem with $47 \%$ clay and silt and $53 \%$ sand. The $0-30 \mathrm{~cm}$ layer had $3.3 \%$ organic matter, $0.21 \%$ total $\mathrm{N}, 1.9 \%$ organic $\mathrm{C}, 14$ and $31 \mathrm{mg}$ per $100 \mathrm{~g}$ soil of available $\mathrm{P}$ and extractable $\mathrm{K}$, respectively, 9.7\% total $\mathrm{CaCO}_{3}$ and $\mathrm{pH}$ 7.8. Winter wheat was the preceding crop in both years. The experiment was carried out at the end of the field where weed seed bank composition in the soil was rich. Common cropping practices were applied. Sowing of the imidazolinone-resistant sunflower hybrid NS RIMI was performed mechanically using a pneumatic drill seeder Polt Nodet on April 9, 2008 and May 4, 2009. The seeds were treated with an insecticide and fungicide and then they were treated with a bird repellent during sowing. The inter-row distance was $70 \mathrm{~cm}$, while the distance between plants in the row was $23.5 \mathrm{~cm}$; hence the sowing density amounted to 5560,000 plants $\mathrm{ha}^{-1}$.

The application of herbicides included the following variants:

- A - without herbicide application and

- B - application of a combination of flurochloridone $+\mathrm{s}$-metolachlor in the amount of $500 \mathrm{~g} \mathrm{l}^{-1}$ a.i. and $1350 \mathrm{~g} \mathrm{l}^{-1}$ a.i. (Racer $21 \mathrm{ha}^{-1}+$ Dual Gold 1.51 $\mathrm{ha}^{-1}$ ) after sowing but prior to the emergence of sunflower.

Herbicides were applied using a knapsack sprayer on April 17, 2008 and April 24,2009 . After sunflower emergence in both variants A and B, the weeds were manually removed once at five different times, i.e., at five different sunflower growth stages: V1-4 - leaf stage, V2-6 - leaf stage, V3-9 - leaf stage, R1 - budding and R5 flowering. The variants were maintained weeds-free from the moment of weed removal to sunflower harvest. Each variant had three replications. The basic plot was $10 \mathrm{~m}$ long and $4.2 \mathrm{~m}$ wide, i.e., four sunflower rows. Weed infestation was estimated at the different sunflower growth stages, i.e. during weed removal, weed samples were taken from two $0.25 \mathrm{~m}^{2}$ squares $(70 \times 35.7 \mathrm{~cm})$ located in the two middle sunflower rows. The number of species, the number of plants per weed spe- 
cies and the weed fresh biomass per sample were determined. Simultaneously, in order to monitor the effects of weeds in relation to the herbicides application and the duration of competition, the sunflower plant height was calculated by measuring 10 plants each from the middle rows. At the end of the growing cycle, the grain yield with $11 \%$ moisture was obtained. In the laboratory, the oil content was measured in order to learn what the weed influence was on the sunflower yield quality.

The obtained experimental data were processed by a mathematical statistical procedure using the statistical package STATISTICA 8.0 for Windows (Analytical software, Faculty of Agriculture, Novi Sad, Serbia). The differences between the means were tested by the least significant difference (LSD) test at the $5 \%$ probability level.

\section{Meteorological conditions}

The mean daily air temperatures during the growing season in both years of investigation were higher than the long-term average $\left(19.0^{\circ} \mathrm{C}\right)$, while the total precipitation sum from April to September was significantly lower than the long term average (320.8 mm). If compared, 2008 and 2009 did not differ much from each other in relation to the average monthly air temperatures $\left(20.3\right.$ and $20.9^{\circ} \mathrm{C}$, respectively), but the precipitation was lower in $2009(178.4 \mathrm{~mm})$ than in 2008 (223.6 $\mathrm{mm}$ ). A dry spell in April 2009 with only $7.3 \mathrm{~mm}$ of precipitation was especially important because it coincided with the sowing of sunflower and the application of herbicides.

Table 1: Average monthly air temperatures and monthly precipitation sums from April to September at Zemun Polje

\begin{tabular}{lcccccc}
\hline \multirow{2}{*}{ Months } & \multicolumn{5}{c}{ Temperature $\left({ }^{\circ} \mathrm{C}\right)$} & \multicolumn{3}{c}{ Precipitation $(\mathrm{mm})$} \\
\cline { 2 - 7 } & 2008 & 2009 & $1998-07$ & 2008 & 2009 & $1998-07$ \\
\hline April & 14.1 & 15.8 & 13.3 & 27.3 & 7.3 & 52.6 \\
May & 19.3 & 19.8 & 18.2 & 39.7 & 27.4 & 44.3 \\
June & 23.0 & 21.0 & 21.7 & 36.3 & 71.9 & 89.6 \\
July & 23.5 & 24.1 & 22.5 & 46.2 & 31.2 & 56.6 \\
August & 24.2 & 23.9 & 20.5 & 19.7 & 36.6 & 56.8 \\
September & 17.5 & 20.6 & 17.9 & 54.4 & 4.0 & 50.9 \\
Average/Sum & 20.3 & 20.9 & 19.0 & 223.6 & 178.4 & 320.8 \\
\hline
\end{tabular}

\section{RESULTS AND DISCUSSION}

According to the obtained results, weed infestation of the sunflower crop significantly differed depending on the application of herbicides, especially in 2008 (Tables 2 and 3). Different meteorological conditions influenced the activity of the soil-applied herbicides in both years. Extremely low sums of precipitation in April and May in 2009 caused low efficiency of the herbicides which were applied. In each period, i.e., at each growth stage the number of weed species, the number of plants 
per weed species and the total fresh and dry weed biomass, TFWB and TDWB, respectively, were, as expected, higher on the areas that had not been treated (A) than on the herbicide-treated areas (B). In each year, eight weed species were the most distributed, with the order shown in Tables 2 and 3. A. artemisiifolia was the most abundant weed species in the sunflower crop in 2008. This invasive and very detrimental weed species was present in an even greater number of plants in the variant with herbicides application. In the same variant, the following remaining species were detected: $X$. strumarium, Chenopodium hybridum, S. nigrum, D. stramonium and S. halepense. In both variants Veronica persica, Stachys annua, Polygonum lapathifolium, Abuthilon theophrasti and Reseda lutea were scarcely distributed weed species, with a small number of plants and a small biomass.

Table 2: Effects of the applied herbicides on weed abundance at different stages of sunflower development (the fresh biomass per weed species $\mathrm{m}^{-2}$ ) in 2008

\begin{tabular}{|c|c|c|c|c|c|c|c|c|c|c|}
\hline \multirow{3}{*}{ Weed species } & \multicolumn{10}{|c|}{ Time of estimation of weed infestation in sunflower crop } \\
\hline & \multicolumn{2}{|c|}{ V1 } & \multicolumn{2}{|c|}{ V2 } & \multicolumn{2}{|c|}{ V3 } & \multicolumn{2}{|c|}{ R1 } & \multicolumn{2}{|c|}{ R5 } \\
\hline & $\bar{A}$ & $\mathrm{~B}$ & $\bar{A}$ & $\mathrm{~B}$ & A & $\mathrm{B}$ & $\bar{A}$ & $\mathrm{~B}$ & $\bar{A}$ & $\mathrm{~B}$ \\
\hline AMBAR & 10.9 & 2.0 & 60.2 & 6.7 & 101.2 & 23.4 & 1685.3 & 645.2 & 3088.6 & 1501.2 \\
\hline XANST & 2.8 & 13.7 & 52.4 & 5.7 & 83.4 & 27.0 & 268.6 & 365.9 & 769.7 & 1096.9 \\
\hline CHEAL & 4.3 & & 5.7 & & 26.3 & & 343.1 & 3.4 & 315.9 & 33.9 \\
\hline SORHA & 6.9 & 10.5 & 20.4 & 10.7 & 11.2 & 5.8 & 165.7 & 96.5 & 34.3 & 228.7 \\
\hline DATST & 0.3 & & 1.7 & 0.4 & 2.3 & & 37.3 & & 72.3 & 4.5 \\
\hline SOLNI & 0.6 & & 0.7 & & 0.7 & & 31.5 & & 56.6 & 1.3 \\
\hline CHEHY & & & 3.9 & & 6.4 & & 26.7 & & 29.4 & \\
\hline AMARE & 0.3 & & 0.3 & & 0.9 & & 9.0 & & 4.3 & \\
\hline $\begin{array}{l}\text { NWS } \\
\text { NWP }\end{array}$ & $\begin{array}{c}9 \\
146.7\end{array}$ & $\begin{array}{c}3 \\
57.3\end{array}$ & $\begin{array}{c}12 \\
181.5\end{array}$ & $\begin{array}{c}4 \\
56.6\end{array}$ & $\begin{array}{c}10 \\
171.3\end{array}$ & $\begin{array}{c}4 \\
72.7\end{array}$ & $\begin{array}{c}9 \\
178.0\end{array}$ & $\begin{array}{c}5 \\
48.7\end{array}$ & $\begin{array}{c}8 \\
230.3\end{array}$ & $\begin{array}{c}6 \\
106.7\end{array}$ \\
\hline TFWB & 27.7 & 26.2 & 147.9 & 23.5 & 234.9 & 56.6 & 2582.2 & 1128.7 & 4371.1 & 2866.5 \\
\hline TDWB & 5.5 & 3.8 & 27.5 & 4.9 & 45.8 & 9.5 & 428.2 & 155.9 & 894.2 & 490.6 \\
\hline
\end{tabular}

The number of plants per weed species and their fresh and dry biomass increased with the growth and the development of sunflower and it was the highest at the beginning of flowering (R5) in both variants, treated and untreated (230.3 and 106.7 plants $\mathrm{m}^{-2} ; 4371.1$ and $2866.5 \mathrm{~g} \mathrm{~m}^{-2} ; 894.2$ and $490.6 \mathrm{~g} \mathrm{~m}^{-2}$ ), Table 2 . Although sunflower, as a robust plant, is a good competitor among row crops, the application of only soil herbicides after sowing and before emergence was not a sufficient measure to protect the crop from the deleterious effects of weeds.

The dominant weed species in 2009 was again A. artemisiifolia, and also D. stramonium, X. strumarium, Chenopodium hybridum, $S$. nigrum and $S$. halepense. All the weed parameters that changed over the sunflower development stages were higher in this year because of the low herbicide efficiency and high weed seed bank potential, Table 3 . The TFWB and TDWB had higher values in the sun- 
flower budding and flowering stage (6445.7 and $6125.0 \mathrm{~g} \mathrm{~m}^{-2} ; 1131.0$ and $1038.4 \mathrm{~g}$ $\mathrm{m}^{-2}$ ). The magnitude of the interference of weeds with sunflower was directly related to both the density of the weed infestation and the length of time during which interference occurred. Weed plants create a different competition pressure on the sunflower crop depending on the development stage, habitus and abundance (Zollinger and Dexter, 1994). Hence, weed infestation increased with progressing of the sunflower developmental stages, and the greatest values of the TFWB and $T D W B$ were determined during the budding and flowering stage of sunflower. In these variants, the effects of the herbicides also decreased with the passage of time and some thermophilic weed species emerged. Decrease in performance of soilapplied herbicides was observed with increasing weed densities (Taylor and Hartzler, 2000).

Table 3: Effects of the applied herbicides on weed abundance at different stages of sunflower development (the fresh biomass per weed species $\mathrm{m}^{-2}$ ) in 2009

\begin{tabular}{lcccccccccc}
\hline & \multicolumn{8}{c}{ Time of estimation of weed infestation in sunflower crop } \\
\cline { 2 - 12 } Weed species & \multicolumn{3}{c}{ V1 } & \multicolumn{3}{c}{ V2 } & \multicolumn{3}{c}{ V3 } & \multicolumn{3}{c}{ R1 } & \multicolumn{3}{c}{ R5 } \\
\cline { 2 - 12 } & A & B & A & B & A & B & A & B & A & B \\
\hline AMBAR & 233.8 & 87.3 & 261.5 & 189.9 & 1327.2 & 670.5 & 4213.3 & 3428.5 & 4733.2 & 5026.3 \\
DATST & 42.1 & 2.7 & 119.6 & 21.8 & 90.0 & 51.5 & 533.2 & 377.5 & 442.1 & 682.1 \\
XANST & 20.1 & 8.6 & 27.0 & 8.2 & 36.9 & 28.0 & 409.3 & 188.9 & 692.5 & 146.3 \\
CHEHY & 42.3 & 1.7 & 24.7 & & 107.1 & & 341.0 & 115.4 & 248.6 & 177.0 \\
SOLNI & 32.1 & 5.7 & 36.9 & 5.0 & 48.7 & 19.6 & 187.1 & 282.8 & 271.6 & 90.3 \\
SORHA & & 1.3 & 1.7 & 99.0 & 11.3 & 72.2 & 362.9 & 187.0 & 20.0 & 3.0 \\
AMARE & 4.7 & 0.3 & 7.9 & 1.0 & 15.8 & 63.0 & 66.2 & 158.5 & 37.7 & \\
CHEAL & 22.9 & & & & 6.5 & 1.3 & 16.5 & 79.6 & & \\
NWS & 8 & 7 & 7 & 7 & 11 & 8 & 8 & 8 & 7 & 6 \\
NWP & 72.0 & 36.0 & 82.0 & 57.5 & 97.3 & 73.4 & 102.9 & 49.4 & 84.0 & 77.4 \\
TFWB & 398.5 & 107.6 & 479.3 & 326.2 & 1671.6 & 907.0 & 6129.5 & 4663.9 & 6445.7 & 6125.0 \\
TDWB & 77.0 & 20.7 & 94.0 & 71.5 & 331.6 & 226.5 & 1109.7 & 865.3 & 1131.0 & 1038.4 \\
\hline
\end{tabular}

NWS - number of weed species; NWP - number of weed plants per $\mathrm{m}^{2} ;$ TFWB - total fresh weed biomass $\left(\mathrm{g} \mathrm{m}^{-2}\right)$; TDWB - total dry weed biomass $\left(\mathrm{g} \mathrm{m}^{-2}\right)$

Table 4: Effects of the applied herbicides on the agronomic traits of sunflower at different developmental stages (2008-09 average)

\begin{tabular}{lcccccc}
\hline \multirow{2}{*}{ Time of estimation } & \multicolumn{2}{c}{ Sunflower plant height $(\mathrm{cm})$} & \multicolumn{2}{c}{ Sunflower yield $\left(\mathrm{kg} \mathrm{ha}^{-1}\right)$} & \multicolumn{2}{c}{ Oil content \% } \\
\cline { 2 - 7 } & $\mathrm{A}$ & $\mathrm{B}$ & $\mathrm{A}$ & $\mathrm{B}$ & $\mathrm{A}$ & $\mathrm{B}$ \\
\hline V1 & 7.3 & 6.8 & 3231.2 & 3195.3 & 42.6 & 42.5 \\
V2 & 11.3 & 11.0 & 3034.2 & 2817.2 & 42.7 & 42.7 \\
V3 & 21.9 & 21.5 & 2968.2 & 3159.5 & 44.3 & 42.0 \\
V4 & 107.9 & 111.1 & 2382.3 & 2704.5 & 41.7 & 41.6 \\
V5 & 138.8 & 201.6 & 1939.5 & 2921.9 & 29.0 & 41.0 \\
\hline \multirow{2}{*}{ Average } & 57.4 & $70.4^{\star}$ & 2711.1 & $2959.7^{*}$ & 40.1 & $42.0^{\star}$ \\
& $L S D_{0.05}=0.45$ & \multicolumn{2}{c}{$L S D_{0.05}=0.82$} & $L S D_{0.05}=0.85$ \\
\hline
\end{tabular}



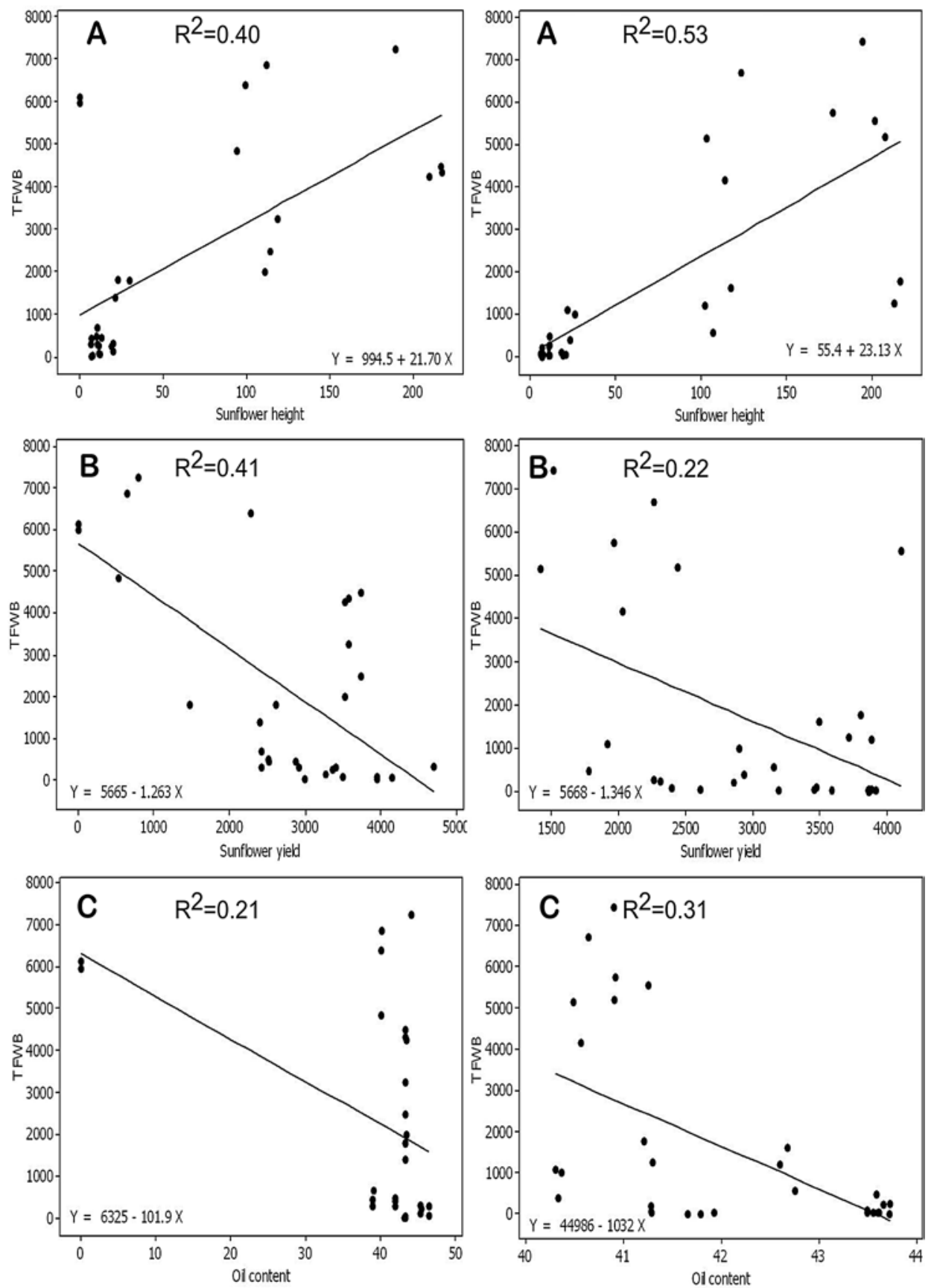

Figure 1: Sunflower height (cm), yield $\left(\mathrm{kg} \mathrm{ha}^{-1}\right)$ and oil content (\%) in dependence on the total fresh weed biomass, TFWB $\left(\mathrm{g} \mathrm{m}^{-2}\right)$ in the herbicide untreated (A) and treated variant $(B)$ 
The primary reason for controlling weeds in sunflower is to prevent yield losses. Weeds may reduce the yield, increase the moisture of the crop at harvest and increase the number of damaged seeds. The presence of weeds also requires slower combine speeds. The present results show that the sunflower plant height, the yield and the oil content were not very different between the variants with and without the herbicide application at the beginning of the sunflower growth (V1, V2, V3), Table 4. Later, during the sunflower budding and flowering stages, after the weed competition had lasted longer, the differences between the measured parameters of sunflower for the treated and untreated variants were greater.

The plant height, the yield and the oil content were previously found to be lower in the untreated control group than in the treated one (Channappagoudar et al., 2008). Similarly, Durgan et al. (1990) evidenced that the sunflower yield and dry weight decreased as weeks of kochia (Kochia scoporia (L.) Schrad)) competition increased. Competition between row crops and weeds occur during the initial stages of emergence and the formation of the first leaves (Simić, 2003; Vratarić 2004). Only two weeks of the kochia competition after sunflower emergence decreased the sunflower achene yield by $6 \%$. The sunflower achene weight, oil content and the plant height were not influenced by various densities or durations of the kochia competition. In the present investigation, the plant height, yield and the oil content were, on average, significantly higher in the herbicide treated variant (57.4 and $70.4 \mathrm{~cm} ; 2711.1$ and $2959.7 \mathrm{~kg} \mathrm{ha}^{-1}$; 40.1 and 42.0\%). The achene yields of the treated and untreated variants did not differ at the beginning of the sunflower growing period. With prolonged time in which the weeds affected the crop and competed for light, necessary nutrients and water, the differences in yields became greater due to the adverse effects of weeds. Based on studies performed in southern Ontario, the time required for weeds to reduce soybean yields by $2.5 \%$ ranged from nine to 38 days (Van Acker et al., 1993).

According to regression analysis of the obtained results, the sunflower plant height, yield and the oil content were changed to various degree on the herbicide untreated and treated variants (Figure 1).

The greater the total fresh biomass of weed was, the greater the plant height of sunflower was, especially in the variant untreated with herbicides. The stronger the weed infestation was, the lower sunflower yield and oil content were. This trend was also more pronounced in the areas without applied herbicides.

\section{CONCLUSIONS}

The results obtained in this study indicate that the weed abundance in sunflower crops which are grown under the agroecological conditions of Zemun Polje is greatly dependent on the meteorological conditions. Namely, it was higher in the year when the conditions affected the efficiency of the soil herbicides which were applied. The intensity of weed infestation of sunflower was lower in the treated var- 
iant, especially in 2008, and changed in dependence on the crop developmental stages. The applied herbicides flurochloridone + s-metolachlor reduced the number of annual broad-leaf species S. nigrum, D. stramonium, A. retroflexus, Ch. album and Ch. hybridum, while the effect of the herbicides on the most dominant species, $A$. artemisiifolia and $X$. strumarium, was unsatisfactory.

The weed infestation level expressed by the total fresh weed biomass affected the sunflower height during vegetation stages, as well as the yield and the oil content at the end of the growing cycle.

\title{
ACKNOWLEDGEMENT
}

\author{
This study was supported by the Ministry of Science and Technology of \\ the Republic of Serbia through Project III 46008.
}

\section{REFERENCES}

Anonymous, 2002. Agricultural Data. FAOSTAT. Available online at: http://faostat.fao.org.

Bosnić, A.Č., Swanton, C.J., 1997. Influence of barnyard grass (Echinochloa crus-galli) time of emergence and density on corn (Zea mays). Weed Science 45: 276-282.

Castro-Tendero, A.J., García-Torres, L., 1995. SEMAGI-an expert system for weed control decision making in sunflowers. Crop Protection 14: 543-548.

Channappagoudar, B.B., Biradar, N.R., Bharamagoudar, T.D., Rokhade, C.J., 2008. Physiological Studies on Weed Control Efficiency of Different Herbicides in Sunflower. Karnataka Journal of Agricultural Sciences 21: 165-167.

Durgan, R.B., Dexter, G.A., Miller, D.S., 1990. Kochia (Kochia scoparia) Interference in Sunflower (Helianthus annuus). Weed Technology 4: 452-456.

Demirer, T., Ozer, I., Kocturk, O.M., Yesilyurt, E.A., 2004. Effect of Different Leaf Fertilizers on Yield and Quality in Sunflower (Helianthus annuus L.). Pakistan Journal of Biological Sciences 7: 384-388.

Jaykumar, R., Premsekar, M., Kempuchetty, N., Subramaniam, S., 1988. Effect of integrated weed management on yield and quality of sunflower. Madras Agricultural Journal 75: 304.

Knežević, S.Z., Horak, M.J., Vanderlip, R.L., 1997. Relative time of redroot pigweed (Amaranthus retroflexus L.) emergence is critical in pigweed-sorghum (S. bicolor (L) Moench.) competition. Weed Science 45: 502-508.

Konstanović, B., Meseldžija, M., Korać, M., 2010. Weed florae and efficiency studies of herbicides in sunflower crops. Plant protection. [Korovska flora i ispitivanje efikasnosti herbicida u usevu suncokreta. Zaštita bilja] 61: 87-95.

Malidža, G., Glušac, D., Orbović, B., 2005. Current situation and trends in the field of chemical weed control in sunflower. Proceeding of the Institute of Field and Vegetable Crops Novi Sad. [Aktuelna situacija i tendencije na polju hemijskog suzbijanja korova u suncokretu. Zbornik radova Naučnog Instituta za Ratarstvo i Povrtarstvo Novi Sad] 41: 473-480.

Malidža, G., Jocić, S., Škorić, D., Orbović, B., 2004. Clearfield system of sunflower production. Proceeding of the Institute of Field and Vegetable Crops Novi Sad. Clearfield sistem proizvodnje suncokreta. [Zbornik radova Instituta za Ratarstvo i Povrtarstvo] 40: 279290.

Onofrio, A., Tei, F., 1994. Competitive ability of threshold levels of three broadleaf weed species in sunflower. Weed Research 34: 471-480.

Singh, M., Saxena, M.C., Abuirmaileh, B.E., Thahabi, S.A.L., Haddad, N.I., 1996. Estimation of Critical Period of Weed Control. Weed Science 44: 273-283.

Simić, M., 2003. The seasonal dynamics of the weed community, competitiveness and productivity of maize withtin the integrated weed management system. PhD thesis. Universisty of Belgrade, Faculty of Agriculture. [Sezonska dinamika korovske sinuzije, kompeti- 
tivnost i produktivnost kukuruza u integralnim sistemima kontrole zakorovljenosti. Doktorska disertacija. Univerzitet u Beogradu, Poljoprivredni fakultet] pp. 1-199.

Taylor, L.K., Hartzler, G.R., 2000. Effect of Seed Bank Augmentation on Herbicide Efficacy. Weed Technology 14: 261-267.

Van Acker, R., Weise, S.F., Swanton, C.J., 1993. Influence of interference from a mixed weed species stand on soybean (Glycine max (L.) Merr.) growth. Canadian Journal of Plant Sciences 73: 1293-1304.

Vratarić, M., 2004. Weeds in sunflower and theirs control. In: Sunflower, Helianthus annuus L., The Agricultural Institute Osijek, Osijek, Croatia. [Korovi u suncokretu i njihovo suzbijanje. U: Suncokret, Helianthus annuus L., Poljoprivredni Institut Osijek, Osijek, Hrvatska], pp. 259-282.

Zollinger, R.K., Dexter, A.D., 1994. Sunflower production. North Dakota State University Extension Bulletin: 25.

\title{
LOS EFECTOS DE LOS HERBICIDAS APLICADOS CONTRA LA INFESTACIÓN POR LAS MALAS HIERBAS DE GIRASOL (Helianthus annuus L.) EN DIFERENTES ESTADIOS DE DESENROLLO Y PRODUCTIVIDAD
}

\author{
RESUMEN
}

El nivel de infestación por malezas afecta directamente la intensidad de las relaciones de competencia entre los cultivos de girasol y las malas hierbas. Los mayores daños se sufren por las malas hierbas anuales, de hojas anchas e invasivas, tales como Ambrosia artemisiifolia L., Xanthium strumarium L. y Datura strmonium L. A eliminación de estas malezas es difícil debido a la falta de herbicidas adecuados y la ausencia de efectos cuando se aplican herbicidas en años con primaveras secas como fue en el 2009. Este estudio de dos años trata de los efectos observados de aplicar en pre-emergencia el herbicida flurochloridone + metolachlor en malas hierbas distribuidas en cultivos de girasol a diferentes etapas de su desarrollo. La infestación de malezas se calcula sobre las etapas del desarrollo del girasol, es decir, en los períodos cuando las malas hierbas son eliminadas y cuando el total de biomasa fresca y seca de las especies de malas hierbas son determinadas. Al mismo tiempo, con la finalidad de controlar los efectos de las malas hierbas dependiendo de la aplicación de los herbicidas y la duración de la competencia, se medió la altura de las plantas de girasol. Al final de un ciclo de vida, fue medido el rendimiento y el contenido de aceite de girasol.

El total de biomasa fresca de las malezas cambia dependiendo de las etapas de desarrollo del girasol y fue siempre menor en las áreas donde hudo tratamiento con el herbicida. Esto afectó la altura de la planta de girasol, el rendimiento y el contenido de aceite que eran más altos, en media, en las variedades con las aplicaciones de herbicidas $\left(70.4 \mathrm{~cm}, 2.959,7 \mathrm{~kg} \mathrm{ha}^{-1}\right.$ y $\left.42,0 \%\right)$ que en las variedades sin la aplicación de herbicidas $\left(57.4 \mathrm{~cm}, 2.711,1 \mathrm{~kg} \mathrm{ha}^{-1}\right.$ y $40.1 \%)$. La eliminación de las malas hierbas en el cultivo de girasol se tiene que hacer con herbicidas adecuados, a su debido tiempo, para conseguir una reducción significativa de los parámetros morfológicos y de rendimiento. 


\title{
EFFETS DE L'APPLICATION D'HERBICIDES SUR L'ENHERBEMENT A DIFFERENTS STADES DE DEVELOPPEMENT DU TOURNESOL (Helianthus annuus L.) ET SUR SA PRODUCTIVITE
}

\author{
RÉSUMÉ
}

Le niveau d'enherbement affecte directement la récolte du tournesol. Les mauvaises herbes annuelles, invasives et à larges feuilles comme Ambrosia artemisiifolia L., Xanthium strumarium L. and Datura stramonium L. sont les plus compétitives. L'élimination de ces mauvaises herbes est rendue difficile par le manque d'herbicides efficaces, en particulier dans les années avec un printemps sec, comme en 2009. Cette étude sur deux ans porte sur les effets observés de deux herbicides de pré-émergence, flurochloridone et metolachlor, sur les mauvaises herbes, à différents stades de développement du tournesol. La biomasse totale des mauvaise herbes a été mesurée pendant les différents stades de développment du tournesol, ainsi que la hauteur des plantes en culture. La production et le contenu en huile ont été évalués après récolte.

La biomasse fraîche de mauvaises herbes fraîches a évolué avec le stade de développement de la culture, mais a toujours été diminuée par les traitements. L'application d'herbicides a augmenté en moyenne la hauteur de 70,4 $\mathrm{cm}$, la récolte de $2959 \mathrm{~kg} \mathrm{ha}^{-1}$, et le rendement en huile moyen des plantes de $42 \%$ par rapport au témoin sans herbicide.

Pour le tournesol, l'application d'herbicide doit donc être faite avec les molécules appropriées, et au bon stade, pour avoir un effet significatif, non seulement sur les mauvaises herbes, mais aussi sur les paramètres de croissance et de production. 
